\title{
Preventive and Promotional Effort for Type 2 Diabetes Mellitus based on Local Resources
}

\author{
Oliva Suyen Ningsiha), Fransiska Widyawati, Bonavantura N.Nggarang, Alberika \\ Sindriyani D.Jehoman, Dorotea Nasvia, Karolus Fransiskus Tono
}

\author{
Universitas Katolik Indonesia Santu Paulus Ruteng, Ruteng, Indonesia \\ a)Corresponding Author: osningsih@gmail.com
}

\begin{abstract}
The people of Gendang Rejeng are potentially at a higher risk of type 2 diabetes due to their unhealthy lifestyle and eating habits linked to their traditional practices. There are efforts to identify the potential risk of type 2 diabetes and carry out preventive and promotive measures based on local potentials. The efforts include: 1) health check-ups; 2) diabetes screening; 3) health education; and 4) discussion with community leaders on adapting traditional practices to be more health-friendly. Through the study we discovered that out of 29 people of Gendang Rejeng that had been screened for diabetes, $62.1 \%$ had a low risk, $13.8 \%$ had a higher risk, and the remaining $24.1 \%$ had a moderate risk of diabetes. There is a need to study local potentials and traditional elements which can be incorporated into the efforts to reduce the risk of diabetes and prevent other health complication. Ginger is an example of one of the local potentials that can be utilized for consumption to improve the health of the people of Rejeng

Key words: Preventif dan promotif, diabetes mellitus, local resources
\end{abstract}

\section{INTRODUCTION}

This community service partnership program engages traditional leaders and communities in the village of Gendang Rejeng in Bangka Lelak Village, Manggarai, East Nusa Tenggara. These partners are economically and socially unproductive. Gendang Rejeng has 105 families with a total population of 615 people (Bangka Lelak, 2020). As an indigenous people, this village has a distinctive socio-cultural structure which is led by a traditional leader called tu'a golo or tu'a, and assisted by tu'a panga, tu'a teno and several other tu'a. The Manggarai people as a whole are still very respectful and obedient to traditional leaders and in carrying out traditional ceremonies (Lon, Yohanes; Widyawati, 2020).

There are many traditional ceremonies ranging from pregnancy to death. In a year one family can carry out a minimum of 10 large/small traditional ceremonies. So in one traditional village, there can be dozens of traditional parties. During traditional rituals, many animals are slaughtered. Abundant processed meat meets the traditional party menu which is usually served with rice. In addition, several times a day there are drinks in the form of coffee and sweet tea as well as cakes made from carbohydrates and gluten. There is also a local arak which contains alcohol, cigarettes and betel nut. Traditional parties are considered good if meat, drinks, cakes and cigarettes are abundant and people eat to their heart's content. Healthy menus such as vegetables are usually very small portions and tend to be ignored. Moreover, fruits, almost nothing. Alternative carbohydrates, such as corn and sweet potatoes, are also considered inappropriate for a party. There is a kind of mindset that the more food/drinks are served and eaten, the better the traditional party will be.

Many people are not aware of the diseases that can be caused by consuming highcarbohydrate, high-fat foods, drinks that contain lots of sugar, alcohol, smoking and partying habits (sitting, lack of sleep, lack of activity). One of the diseases that can arise as a result of this behavior is type 2 diabetes mellitus. Diabetes mellitus (DM) is a world health problem that can cause increased morbidity and mortality due to complications (Wu, Ding, Tanaka, \& Zhang, 2014). According to data from the Manggarai District Health Office (2019), the prevalence of diabetes mellitus sufferers in Manggarai District in 2019 was 535 people and in Bangka Lelak village as many as 35 people (Manggrai District Health Office, 2019). The increasing prevalence 
of diabetes mellitus is closely related to changes in lifestyle and culture including the habit of consuming unhealthy food intake and lack of physical activity (Sousa, Marujo, Filipa, \& Dias, 2018).

Diabetes mellitus (DM) is characterized by chronic hyperglycemia, impaired carbohydrate, protein and fat metabolism that occurs due to insulin insufficiency (Wu et al., 2014). Some risk factors for DM include non-modifiable risk factors including age, gender, family history of diabetes and modifiable risk factors including unhealthy food intake, smoking, lack of activity, alcohol consumption, hyperlipidemia and obesity (Wu et al. ., 2014). Diabetes can be controlled through increased knowledge, attitudes and behavior of healthy living. These factors become an integral part of comprehensive diabetes mellitus treatment. Unhealthy food intake habits are closely related to obesity and diabetes. Failure to follow the recommended diet and physical activity plan is the main cause of complications in Type 2 DM patients (Ouyang, 2017). Diabetes mellitus patients need strengthening diabetes education including diet management to encourage them to understand better disease management, more appropriate self-care and better quality of life. However, the effectiveness of diabetes management education is also influenced by cultural factors. Successful management of diabetes mellitus including diet management must involve beliefs, local culture, family and patient community networks (Ouyang, 2017).

The people of Rejeng village, Bangka Lelak village have a high risk of developing type 2 diabetes mellitus. Several supporting risk factors include unhealthy food intake habits, lack of physical activity, smoking and alcohol consumption. This behavior is inseparable from the cultural influence of the people of Manggarai Regency in general, including the people of Rejeng village, Bangka Lelak Village. Traditional rituals and party habits affect the lifestyle behavior of the Rejeng villagers, such as consuming high-carbohydrate, high-fat foods, smoking and drinking alcohol and lack of physical activity. This is because in traditional rituals and parties, many animals that are high in fat are usually slaughtered, such as pigs and cows. These animals are processed into various menus such as pork fat chips, pork soy sauce, pork soup, rendang, satay. The types of carbohydrates served in traditional rituals are usually rice, noodles and cakes as well as tea and coffee drinks served after meals. Vegetables are served in small portions while fruit is absent.

Menus served at parties and local alcoholic beverages that are always served during traditional rituals put people at risk for health problems, one of which is type 2 diabetes mellitus. This shows that partners are dealing with major problems in the health sector as well as in the meaning of local culture itself. In terms of health, their problem is that they have a high risk of developing type 2 diabetes mellitus because of their lifestyle, for example the habit of consuming unhealthy food intakes such as high fat and high carbohydrates, consuming less vegetable and fruits. Other risk factors such as lack of physical activity and smoking habits. Traditional rituals make people do less physical activity because during traditional rituals the community is always in a sitting position for a long time as well as during parties that last until late at night. Cigarettes are always served with alcohol during traditional rituals. From a cultural perspective, our initial study shows that society tends to limit and ignore the philosophical, religious and cultural meanings of cultural values because rituals are only seen as limited as a party. When the ritual is only focused on this aspect, the community forgets the main purpose of the ritual for the happiness and well-being of local residents. Today, rituals that can affect the motivation to live a healthy and prosperous life as the ideals of the ancestors are starting to fade by the glamor of the party.

Therefore, dealing with the problems faced by partners must be comprehensive and holistic. Health problems, especially DM disease, must be part of the transformation of local culture. A change in the paradigm or mindset regarding local culture must also have an impact on the commitment of indigenous leaders and peoples to a healthier life. In addition, the local potential in Rejeng village as the largest producer of ginger in Manggarai district can be utilized and managed in the short term as an herbal drink to reduce blood glucose levels in type 2 DM patients in Rejeng village, Bangka Lelak village. The results of research conducted by Mahluji 
et.al (2013) showed that ginger (Zingiber officinale) can significantly improve insulin sensitivity and reduce fat levels in patients with type 2 diabetes mellitus. According to Suharto (2019), the phenolic content in ginger can reduce blood glucose levels. In addition, ginger is useful in lowering triglyceride and cholesterol levels in the blood. This ginger drink can be used as an alternative drink that is served during traditional rituals and parties to replace tea and coffee.

Therefore, to overcome the problem of partners who have a high risk of experiencing type 2 diabetes mellitus which is influenced by cultural factors, the solution is to carry out community service activities that are packaged simultaneously, in the health and socio-cultural fields, which include conducting health checks, screening the risk of type $23 \mathrm{DM}$, educating the causes, effects and management of DM, and finding together with leaders and indigenous peoples how to interpret and manage traditional parties that are friendly to health, economy and ecology. The promotive solution is training residents to recognize and manage healthy food and drinks around the village, especially ginger which should be consumed by the family daily or during traditional parties and as a prevention and treatment of DM.

\section{METHOD}

This community service was carried out in the Rejeng village, Bangka Lelak village in May 2021 with a total of 29 respondents. Activities carried out include preventive and promotive actions. Preventive actions include health checks, DM risk screening, education on the causes, effects and management of DM disease, dialogue with leaders and indigenous peoples to interpret and manage traditional parties that are friendly to health, economy and ecology. Promotive actions include: training residents to recognize and process healthy food and drinks around the village, especially ginger. The tools used for health checks are blood glucose test meter to measure blood sugar levels, blood pressure meter and stethoscope to measure blood pressure, scales to measure body weight, and a meter to measure height and abdominal circumference.

\section{RESULTS}

The characteristics of the Gendang Rejeng community are mostly aged 45 years as many as $22(75.9 \%)$, female sex as much as $14(48.3 \%)$ and male sex as much as $15(51.7 \%)$. The people of Gendang Rejeng are mostly farmers with income $<1,000,000 /$ month. Health checks for the Gendang Rejeng community include age, gender, body mass index (BMI) , abdominal circumference, blood pressure and current blood sugar. The results of the examination showed that most of the normal weight was $16(55.2 \%)$, overweight $4(13.8 \%)$, obesity 1 was eight (27.6) , obesity 2 was one (3.4\%), abdominal circumference < 90 in men was $15(51.7 \%)$ and abdominal circumference $<80$ in $14(48.3 \%)$ women. The results of blood pressure examination showed as many as $17(58.6 \%)$ with normal blood pressure, nine (31.0) with pre-hypertension, two $(7 \%)$ with grade one hypertension, one (3.4\%) with grade two hypertensions. As many as 23 $(79.3 \%)$ with blood sugar when $<200 \mathrm{mg} / \mathrm{dl}$ and as many as six $(20.7 \%)$ with blood sugar when $200 \mathrm{mg} / \mathrm{dl}$.

After the health examination, screening for type 2 diabetes mellitus is carried out. Screening for type 2 diabetes mellitus uses the Finnish Diabetes Risk Score (FINDRISC) which aims to predict the risk of diabetes mellitus in the next 10 years. FINDRISC predicts type 2 diabetes mellitus by looking at several risk factors including age, body mass index, abdominal circumference, history of high blood pressure medication use, history of high blood sugar, family history of DM, daily consumption of vegetables or fruit and physical activity. Screening results for type 2 diabetes mellitus showed that as many as $18(62.1 \%)$ had a low risk of type 2 diabetes mellitus, the risk slightly increased by 4 (13.8\%), moderate risk was seven (24.1\%).

\section{DISCUSSION}

The results of the health examination showed several health problems experienced by the indigenous people of Gendang Rejeng. These health problems include excess weight, obesity, hypertension and increased blood sugar levels. Epidemiological studies show that obesity and hypertension are the most important risk factors for type 2 diabetes mellitus (Wu et al., 2014). 
According to a study conducted by (Asiimwe et al., 2020) most respondents with type 2 diabetes mellitus have hypertension. Obesity and hypertension that occur in the Gendang Rejeng community are closely related to unhealthy eating patterns. Unhealthy eating patterns in the Gendang Rejeng indigenous people are caused by a lack of knowledge and behavior related to local culture. Behavior related to local culture that affects unhealthy eating patterns is the number of traditional party activities organized by the Manggarai community, including the Gendang Rejeng community. Based on the results of the Focus Group Discussion (FGD) with the Gendang Rejeng indigenous community, the types of food served during the traditional feast are various processed pork, goat, chicken, satay, noodles, vegetables mixed with meat and rarely served with fruit. Drinks that are usually served are "tuak" (local arak), sopi and beer (alcoholic drinks), coffee and tea. Every traditional event, alcoholic beverages are always served with cigarettes. According to the traditional head of Gendang Rejeng, the presentation of "tuak" during a traditional event is a form of appreciation for the guests who come. However, there are some Manggarai people who misinterpret the use of "tuak" and make it a drink that is consumed in excess. This causes the people of Gendang Rejeng to have a risk of experiencing type 2 diabetes mellitus.

Based on the results of screening and health examinations as well as FGD results, several risk factors for the occurrence of type 2 diabetes mellitus in the Gendang Rejeng indigenous people are hypertension, obesity, lack of physical activity, smoking and alcohol consumption. Lifestyle factors are closely related to the risk of type 2 diabetes mellitus, such as a sedentary lifestyle, lack of physical activity, smoking and alcohol consumption. Other factors that influence the risk of type 2 diabetes mellitus are overweight, obesity, heredity and hypertension (Asiimwe, Mauti, \& Kiconco, 2020).

The people of Gendang Rejeng have a risk of developing diabetes mellitus because of lifestyle factors that are supported by the results of a health examination. These risk factors include overweighting, obesity, hypertension, smoking and alcohol consumption. Hypertension is one of the factors that increase the risk of type 2 diabetes mellitus in the Gendang Rejeng indigenous community. $50 \%$ of clients with hypertension have diabetes mellitus and contribute significantly to micro and macrovascular complications. The risk of cardiovascular disease occurs four times in clients with hypertension and diabetes mellitus compared to individuals with diabetes mellitus without hypertension (Lastra, Syed, Kurukulasuriya, Manrique, \& Sowers, 2014). Hypertension is a non-communicable disease that most often occurs in the majority of the Manggarai community, including the Gendang Rejeng indigenous people. Some of the indigenous people of Gendang Rejeng experience hypertension which contributes to the risk of diabetes mellitus caused by lifestyle and unhealthy food consumption patterns. This is supported by research conducted by (Dewi, Nggarang, \& Sarbunan, 2020) which states that as many as $65 \%$ of the people in Manggarai Regency experience hypertension due to unhealthy eating patterns.

In addition to hypertension, another factor that increases the risk of diabetes mellitus is obesity. Based on research conducted by (Nangge, Masi, \& Oroh, 2018) states that there is a significant relationship between obesity and the incidence of type 2 diabetes mellitus with a $p$ value of 0.000 . The indigenous people of Gendang Rejeng are at risk of obesity and hypertension which contribute to the incidence of diabetes mellitus due to their lifestyle and unhealthy food consumption patterns. One of the patterns of life and consumption of unhealthy food is influenced by cultural factors. Based on the FGD results, the Gendang Rejeng indigenous people, such as the Manggarai community in general, often hold traditional parties that serve various types of processed meat such as pork, chicken, beef and goat, while vegetables and fruits are served in small portions. Drinks served are usually "tuak" (local wine), beer, coffee and tea. Long-lasting traditional parties also cause people to do less physical activity. This causes the Gendang Rejeng indigenous people to be at risk of developing type 2 diabetes mellitus in the long term.

Health education is carried out to overcome the health problems experienced by the Gendang Rejeng indigenous people, especially type 2 diabetes mellitus. Extension materials are 
provided in local languages to make it easier for the Gendang Rejeng indigenous people to understand the counseling materials provided. After the health education was carried out, it was followed by an FGD with traditional leaders and the indigenous people of Gendang Rejeng regarding the introduction of healthy food menus for a traditional party event by utilizing local potential. In addition, the introduction/discovery of local foods that are good for health is also carried out, especially for the prevention of DM. The results of discussions with the community and traditional leaders found that the types of healthy food as a source of carbohydrates originating from the local potential of the Rejeng community were rice and sweet potatoes. Vegetables that can be consumed such as carrots, mustard greens, cassava leaves and fruits such as bananas. For this type of protein, it can come from tempeh and tofu which are quite cheap or also come from nuts.

The results of the FGD also found that one of the local potentials owned by the Rejeng community that can be processed as a drink to improve health is ginger (Zingiber Officinale). Ginger is one of the medicinal plants found in Indonesia. Rejeng Village is one of the ginger producing areas in Manggarai regency. Ginger has various benefits, one of which is lowering blood sugar levels in patients with type 2 diabetes mellitus. In addition, ginger is also useful for lowering triglycerides and cholesterol (Almasdy \& Martini, 2016; Suharto, Lutfi, \& Rahayu, 2019). Ginger processing can be in the form of ginger drink with the following processing stages: 1) Sorting stage. Sorting is done to maintain the quality of the ginger rhizome. Soil and dirt attached to the ginger rhizome are cleaned using pressurized water spray and assisted with a plastic brush. The rotten ginger rhizome is separated from the healthy ginger rhizome. 2) Processing stages: $50 \mathrm{mg}$ of ginger is cut into crosswise slices with a thickness of $3 \mathrm{~mm}$, boiled using $200 \mathrm{ml}$ of water until the stew becomes $100 \mathrm{ml}$. Then this ginger drink can be drunk warm. $50 \mathrm{mg}$ of ginger for one person to consume. This ginger drink can be consumed twice a day after meals (Mahluji et al., 2013). In this service activity, the people of Gendang Rejeng are also trained to process ginger into a drink that can improve health. The Gendang Rejeng community is committed to making ginger drink a drink that is consumed daily to replace alcoholic beverages, tea and coffee.

\section{CONCLUSIONS And RECOMMENDATIONS}

The Gendang Rejeng indigenous people have several risk factors for developing diabetes mellitus in the next 10 years. These risk factors include hypertension, obesity, lack of physical activity, smoking and alcohol consumption. Cultural factors are very influential in the prevention and management of type 2 diabetes mellitus. This program has succeeded in helping them to change the management of organizing traditional parties by paying attention to health aspects such as food and beverage menus, time and activities that are health friendly. In addition, this activity has also succeeded in encouraging the community to take advantage of their local potential, namely the ginger plant to be used for drinks that can improve health.

\section{ACKNOWLEDGMENTS}

This community service activity was carried out with the support of grant funds from the Indonesian Catholic University of Santu Paulus Ruteng in 2020/2021. The writing team would like to thank you for the support.

\section{REFERENCES}

Almasdy, D., \& Martini, R. D. (2016). Pengaruh Pemberian Serbuk Kering Jahe Merah Terhadap Pasien Diabetes Melitus Tipe 2. Jurnal Ipteks Terapan, 3, 161-169.

Asiimwe, D., Mauti, G. O., \& Kiconco, R. (2020). Prevalence and Risk Factors Associated with Type 2 Diabetes in Elderly Patients Aged 45-80 Years at Kanungu District. Journal of Diabetes Research, 2020. https://doi.org/10.1155/2020/5152146

Desa Bangka Lelak. (2020). Gendang Rejeng. Rejeng.

Dewi, F., Nggarang, B. N., \& Sarbunan, H. (2020). Penerapan Asuhan Keperawatan Masalah 
Hipertensi Dan Perilaku Hidup Bersih Sehat Pada Warga Dusun Puarwase Kabupaten Manggarai. Dinamisia: Jurnal Pengabdian Kepada Masyarakat, 5(1), 112-118. https://doi.org/10.31849/dinamisia.v5i1.4302

Dinas Kesehatan Kabupaten Manggrai. (2019). Profil Kesehatan Kabupaten Manggarai. Ruteng.

Lastra, G., Syed, S., Kurukulasuriya, L. R., Manrique, C., \& Sowers, J. R. (2014). Type 2 diabetes mellitus and hypertension: An update. Endocrinology and Metabolism Clinics of North America, 43(1), 103-122. https://doi.org/10.1016/j.ecl.2013.09.005

Lon, Yohanes; Widyawati, F. (2020). Mbaru Gendang, Rumah Adat Orang Manggarai, Flores. Yogyakarta: Kanisius.

Mahluji, S., Attari, V. E., Mobasseri, M., Payahoo, L., Ostadrahimi, A., \& Golzari, S. E. (2013). Effects of ginger (Zingiber officinale) on plasma glucose level, HbA1c and insulin sensitivity in type 2 diabetic patients. International Journal of Food Sciences and Nutrition, 64(6), 682-686. https://doi.org/10.3109/09637486.2013.775223

Nangge, M., Masi, G., \& Oroh, W. (2018). Hubungan Obesitas Dengan Kejadian Diabetes Melitus. E-Journal Keperawatan (e-Kp), 6(1), 6.

Ouyang, C. (2017). Dietary education for patients with type 2 diabetes: failure or success ? Diabetes Manag, 7(5), 377-382.

Sousa, C. N., Marujo, P., Filipa, V., \& Dias, F. (2018). Self-Care Behavior Profiles With Arteriovenous Fistula in Hemodialysis Patients, (June 2020). https://doi.org/10.1177/1054773818787110

Suharto, I. P. S., Lutfi, E. I., \& Rahayu, M. D. (2019). PENGARUH PEMBERIAN JAHE (Zingiber officinale) TERHADAP GLUKOSA DARAH PASIEN DIABETES MELLITUS. Care: Jurnal IImiah IImu Kesehatan, 7(3), 76. https://doi.org/10.33366/jc.v7i3.1363

Wu, Y., Ding, Y., Tanaka, Y., \& Zhang, W. (2014). Risk factors contributing to type 2 diabetes and recent advances in the treatment and prevention. International Journal of Medical Sciences, 11(11), 1185-1200. https://doi.org/10.7150/ijms.10001 


\section{APPENDIX}

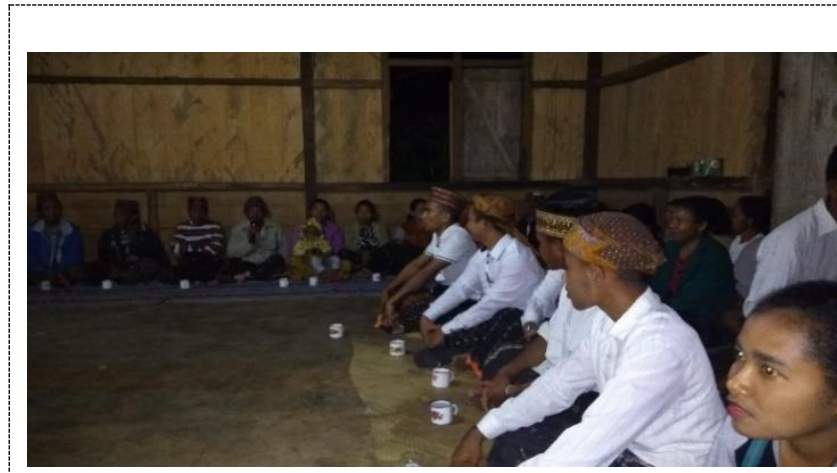

Figure 1. Local wine served during traditional rituals

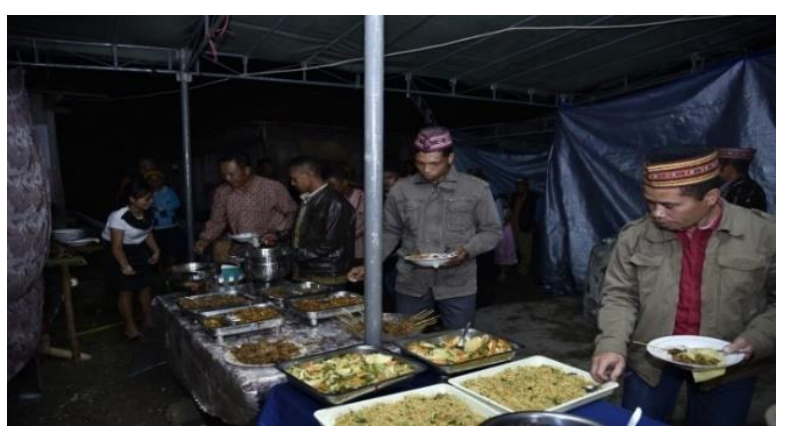

Figure 2. Menu served at the party

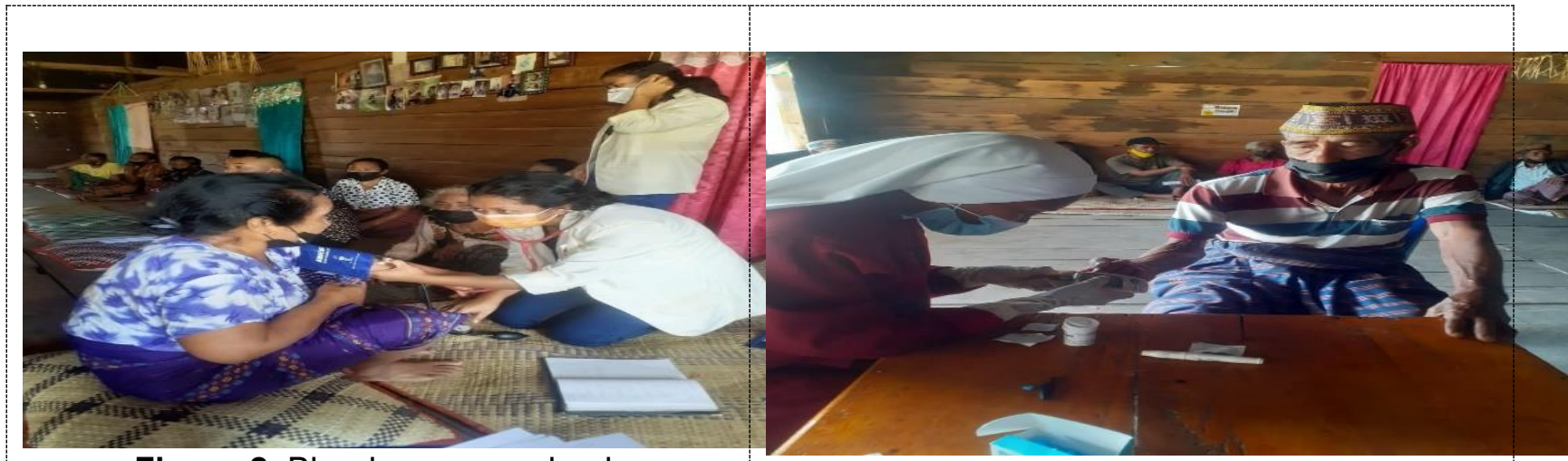

Figure 3. Blood pressure check

Figure 4. Blood sugar check

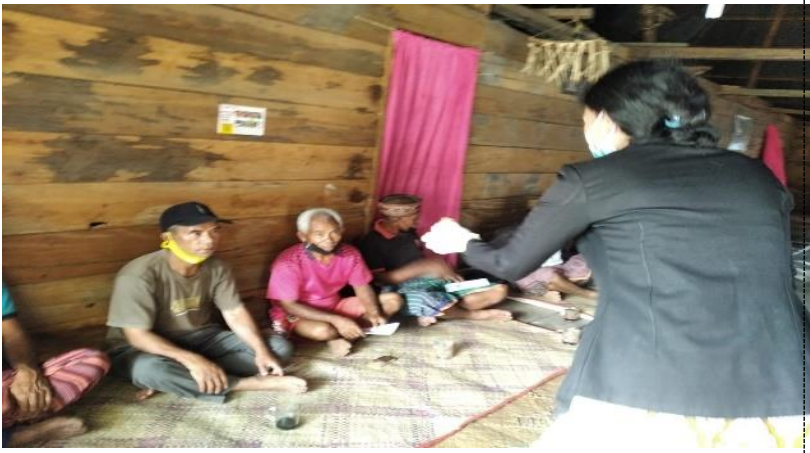

Figure 5. Health education

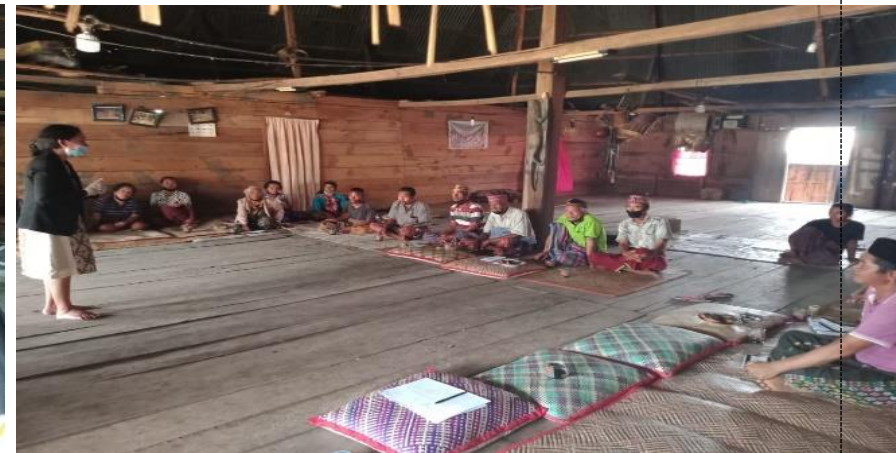

Figure 6. Focus Group Discussion

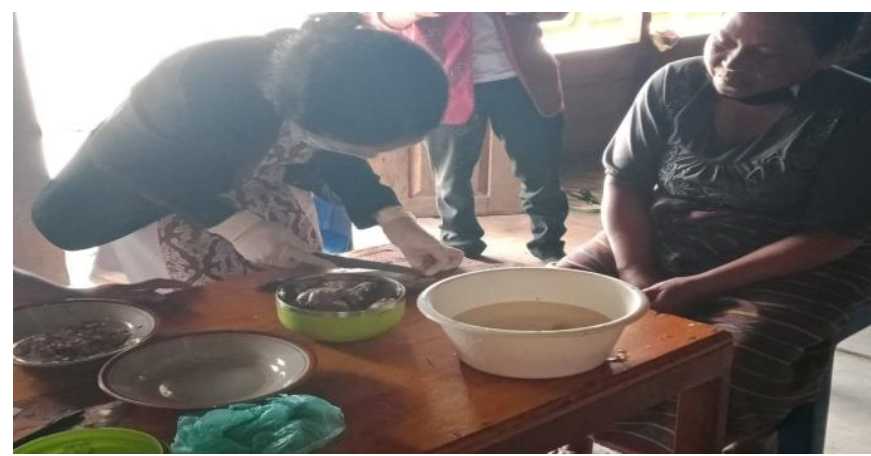

Figure 7. Ginger processing practice 